\title{
Integrated System to Control Primary PM 2.5 from Electric Power Plants
}

\author{
Quarterly Report No. 6 \\ For the Period \\ April 1, 2001 to June 30, 2001 \\ DOE Contract Number DC-FC26-OONT-40757
}

Prepared For:
National Energy Technology Laboratory
U.S. Department of Energy
3610 Collins Ferry Road
Morgantown, WV 26507-0880

DOE Program Manager

Mr. Peter Botros

Prepared By:

LSR Technologies, Inc.

898 Main Street

Acton, MA 01720 


\section{Project Summary}

This is the $6^{\text {th }}$ Quarterly Report under this contract. During this period, the Advanced ElectroCore module precharger and its support frame were installed at Alabama Power Company's E.C. Gaston Steam Plant in Wilsonville, Alabama. This represents the vast portion of the installation work. Ductwork and instrumentation needs to installed before the Advanced ElectroCore module can be tested and demonstrated. Also, the Advanced ElectroCore test plan draft has been prepared, and a design arrangement of a new multipollutant control system with the ElectroCore has been developed.

\section{Advanced ElectroCore Installation}

The cross-trench support frame for the ElectroCore module was fabricated, and the module and its support frame were shipped and installed at Alabama Power Company's E.C. Gaston Steam Plant in Wilsonville, Alabama. The Southern Company has coordinated the ElectroCore installation on behalf of Alabama Power. The attached files in .JPG format contain photos of the ElectroCore installation.

To complete the Advanced ElectroCore test-loop, connecting ductwork lines, dry scrubber and some elements of the water-cooled ElectroCore precharger still need to be designed, fabricated and installed. When completed, the Advanced ElectroCore will be ready for testing and demonstration.

\section{Preparing Advanced ElectroCore Test Plan}

The test plan draft for the ElectroCore has been prepared and sent to DOE, EPRI, and EPA in the first week of September 2001. This test plan addresses the issue of primary PM emissions control as well as the removal of other hazardous air pollutants (HAPs). The key issue concerning PM is the improvement in the collection efficiency of primary particulates with an emphasis on toxic constituents that are associated with small particle sizes. It is intended to demonstrate that a pilot scale (1.5 MWe capacity) ElectroCore ${ }^{\mathrm{TM}}$ installed on a slipstream from a coal-fired utility boiler is able to meet very stringent PM emission regulations. It will also be shown that through the use of chemical sorbents, the ElectroCore can be used as an "enabling technology" in reducing $\mathrm{SO}_{2}$ and mercury emissions. 
A meeting was held in Birmingham, Alabama on August 15 to coordinate all PM and sorbent injection testing. The meeting was attended by representatives of NETL, EPA, EPRI, Alabama Power Company, Southern Research Institute, LSR, and LSR subcontractors. The following is a summary of major discussion topics that were reviewed at the August 15 meeting at SRI:

1. ElectroCore at Gaston Station. Since it is desirable to perform PM tests prior to the $\mathrm{Hg} / \mathrm{SO} 2$ tests, the mercury $\mathrm{CEM}$ will be made available for the entire month of November. Responsibility for operating and maintenance costs during this period will be borne by LSR.

2. A total of six (6) sorbents are to be provided for testing: two(2) from EPA primarily for SO2 and with some Hg capability; three(3)from Merck primarily for $\mathrm{Hg}$ control but with some SO2 capability; and one(1) source of activated carbon from Southern Company.

3. Alabama Power is to notify the state EPA of our intent to perform these tests and the expected increase in PM emissions during sorbent testing. LSR will provide Alabama Power with a letter describing the quantity of PM emissions expected and the percent incremental increase in total PM.

4. LSR is to send SRI an RFP for multipollutant testing support in November, and possibly for PM testing. The RFP is to contain specific technical support items during the $\mathrm{Hg} / \mathrm{SO} / \mathrm{PM}$ testing.

5. Instruments for measuring SO2 and opacity will also be needed during this period. We need to identify a source of these instruments preferably on a loan or rental basis.

6. A test plan draft will be prepared by the LSR team NLT September 4 and submitted to sponsors for review and comment.

\section{Design Arrangement a Multipollutant Emission Control System}

A design arrangement of a novel air emissions control system with the Advanced ElectroCore has been developed. The system will be able to control $\mathrm{SO}_{2}$, mercury, and particulate emissions by means of the ElectroCore incorporated in the system. The patent disclosure "Advanced Emission Control System" has been prepared and submitted to a patent attorney.

\section{Additional Cost-Sharing Support}

A contract was signed by LSR with EPRI in which four EPRI member companies will be contributing to ElectroCore testing. The value of this contract is $\$ 328,000$. 


\section{Work Scheduled for Next Period}

The Advanced ElectroCore test-loop will be complete and shakedown/flow distribution testing, PM testing, and HAP testing will be preformed.

The first set of tests to be conducted will be flow distribution tests. The goal of the tests is to determine the flow distribution among the 12 ElectroCore separators that make up the module. The inlet flow, bleed flow, and clean flow will be measured for each separator and the results compared to determine the separator-to-separator variation.

The particulate testing will be conducted by sampling the gas stream around the Advanced ElectroCore system using EPA Method 5, by Armstrong Environmental, the testing company. The flow rate of gas and particulate matter into the Advanced ElectroCore system will be measured at the precharger inlet. The gas flow rate and mass of particulate leaving with the clean flow will be determined by sampling the clean gas.

The mercury capture efficiency is to be determined for six (6) sorbents: Novit FGD Activated Carbon, three (3) dry sorbents provided by Merck, and two (2) dry sorbents provided by the EPA. In order to compare mercury removal efficiencies with data collected in earlier tests carried out at Gaston, the results of the tests to be conducted with Novit Activated Carbon will act as a baseline. 


\section{ELECTROCORE PILOT UNIT SCHEDULE}

Date

September 14

September 21

September 28

October 1-12

October 15-19

October 30

November 1-9

November $12-16$

November 19-23

November 26-30

December 1-31
Milestone

Arrival of Ductwork / Valves

Installation of Ductwork

Instrument Checkout

Shakedown / Flow Testing

PM Testing

Install Mercury CEM

Mercury CEM Testing

$\mathrm{PM} / \mathrm{SO}_{2} / \mathrm{Hg}$ Testing

Mercury CEM Testing

Mercury Benchmark Testing - SRI

Long Term EC Operation 